\title{
MINERAL RESOURCE POTENTIAL OF THE CHATTAHOOCHEE ROADLESS AREA, TOWNS, UNION, AND WHTE COUNTIES, GEORGIA
}

By

\author{
Arthur E. Nelson and Robert P. Koeppen, U.S. Geological Survey \\ and
}

Robert A. Welsh, Jr. and Ronald W. Mikolajczyk, U.S. Bureau of Mines

1983

Studies Related to Wilderness

\begin{abstract}
Under the provisions of the Wilderness Act (Public Law 88-577, September 3, 1964) and related acts, the U.S. Geological Survey and the U.S. Bureau of Mines have been conducting mineral surveys of wilderness and primitive areas. Areas officially designated as "wilderness," "wild," or "canoe" when the act was passed were incorporated into the National Wilderness Preservation System, and some of them are presently being studied. The act provided that areas under consideration for wilderness designation should be studied for suitability for incorporation into the Wilderness System. The mineral surveys constitute one aspect of the suitability studies. The act directs that the results of such surveys are to be made available to the public and be submitted to the President and the Congress. This report discusses the results of a mineral survey of the Chattahoochee Roadless Area (08029), Chattahoochee National Forest, Town, Union and White Counties, Ga. The area was classified as a furthur planning area during the Second Roadless Area Review and Evaluation (RARE II) by the U.S. Forest Service, January 1979.
\end{abstract}

\section{MINERAI, RESOURCE POTENTIAL SUMMARY STATEMENT}

The Chattahoochee Roadless Area has a low mineral potential and there is little evidence of a potential for the presence of concealed mineral resources. The resource potential for gold, mica, sillimanite, soapstone, dunite, chromite, and nickel is low even though some of these commodities have previously been mined nearby and source rocks for these minerals are present in the area. Granite gneiss, gneiss, schist, metasandstone and quartzite in the area are suitable for crushed rock or aggregate; however, other sources for these materials are available closer to present markets. The potential for hydrocarbons in the area is untested.

\section{INTRODUCTION}

The Chattahoochee Roadless Area occupies approximately $36 \mathrm{sq} \mathrm{mi}$ in the Chattahoochee National Forest of north Georgia. It is centered about $12 \mathrm{mi}$ southeast of Blairsville, Ga. and occupies parts of three counties; the northeast part is in Towns County, the southern half is in White County, and the northwest part is in Union County. It lies in heavily forested terrane and has a rugged topography with narrow valleys, sharp ridges, and steep slopes. Slopes commonly range from 20 to $30^{\circ}$ and in places exceed $45^{\circ}$; rarely are they less than $10^{\circ}$. The highest elevation is $4,045 \mathrm{ft}$ on Horsetrough Mountain, and the lowest is $1,660 \mathrm{ft}$ in Horton Creek west of Helen in the south. Tributaries of the north-flowing Hiwassee River, the south-flowing Chattahoochee River, and the northwest-flowing Nottely River drain the Chattahoochee Roadless Area.

State routes $17,66,180$, and the scenic Richard Russell Highway (348) lead to roads and trails that give limited access to the study area. In addition, the Appalachian Trail traverses parts of the area's high ground.
Previous Work

Yeates and others (1896) described the gold deposits and mining properties of Georgia. One of the major gold-producing zones they described lies in a belt of rocks that extends northeast from Dahlonega and is called the Dahlonega gold belt. Rocks in this belt are very close to the southeasternmost part of the Chattahoochee Roadless Area. Furcron and Teague (1943) described the mica-bearing pegmatites of Georgia; some of these pegmatites are within the Chattahoochee National Forest near the study area. Crickmay (1952) described the crystalline rocks of Georgia, and Hurst (1973) wrote about the general geology of the southern Blue Ridge belt. Hartley (1973) described the ultramafic rocks present along the northwest border of the Chattahoochee Mountain area. Hatcher (1971) reported on the geology of nearby Rabun and Habersham Counties, Ga., and he also reported on the tectonic history of northern Georgia (Hatcher, 1974). The general geology of the Chattahoochee area is shown on the geologic map of Georgia (Georgia Geological Survey, 1976). The geology of the study area is detailed in Nelson (1983). 


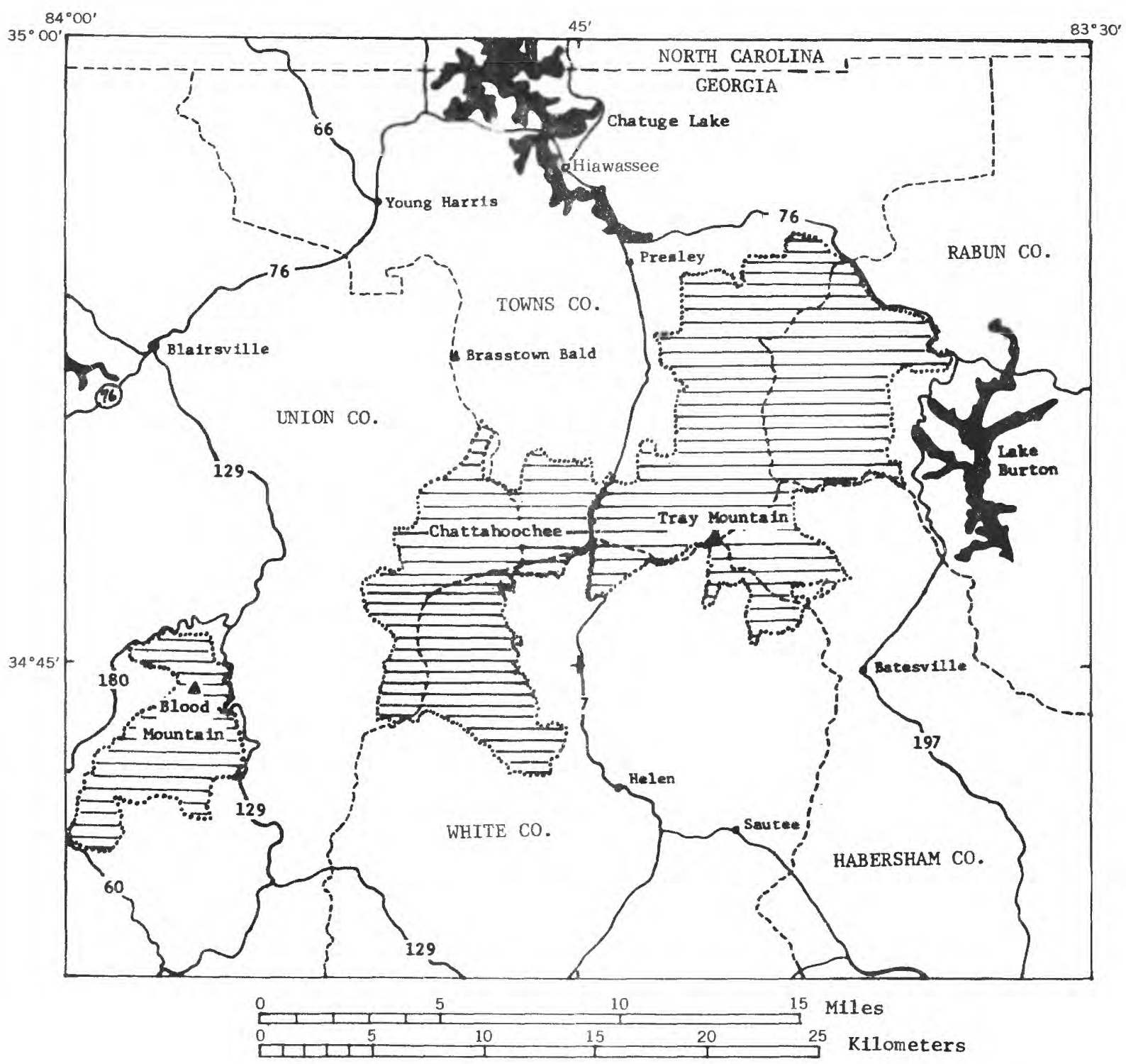

Figure 1.--Index map showing location of Chat tahoochee, Tray Mountain, and Blood Mountain Roadless Areas (ruled areas). 


\section{Present Work}

During the spring and fall of 1980, A. E. Nelson and J.S. Schindler completed a reconnaissance map and sampling study of the Chattahoochee Roadless Area (fig. 2). Stream-sediment samples were collected under the direction of Robert Carpenter of the University of Georgia. Complete analyses of these samples is available in Seims and others (in press).

R. A. Welsh and R. W. Mikolajczyk, assisted by M. L. Dunn, Jr., J. G. Jones, and A. E. Sabin, conducted field studies for the U.S. Bureau of Mines in the fall of 1981 . They collected 26 rock samples, 36 panned concentrates, and 16 sluiced concentrates and studied abandoned mines and quarries, mica prospects, and gold placer mines in or nearby the study area. Analyses of the samples was made by TSL Laboratories, Ltd., Spokane, Wash., and by the U.S. Bureau of Mines, Reno Research Center, Reno, Nev. (Welsh and Mikolajczyk, 1982).

\section{Acknowledgments}

We wish to thank Steve Briggs and Cliff Wilson, U.S. Forest Service land officers, and Tom Hawks, Chattooge District Ranger, who aided this investigation by providing information concerning mineral mining and prospecting activity in the study area. Mr. Dale Jackson of Helen, Ga., was a valuable source of information concerning placer mining in Dukes Creek Valley.

\section{SURFACE- AND MINERAL-RIGHTS OWNERSHIP}

U.S. Forest Service records indicate that the Federal Government owns surface rights to more than 99 percent of the Chattahoochee Roadless Area. Mineral rights in the study area are 71 percent Federally owned and 29 percent privately owned (fig. 3). Privately-owned mineral rights are held in perpetuity, and most are in third-party ownership.

Amoco Production Company leased 144 acres in the study area for oil and gas exploration, effective through July 1, 1992, and lease applications for an additional 4,300 acres have been submitted to the Bureau of Land Management for approval (fig. 4).

\section{GEOLOGY}

The Chattachoochee Roadless Area is underlain chiefly by metamorphosed allochthonous rocks of two thrust sheets. The northwest border of the area is underlain by part of a narrow thrust sheet of mafic ultrama fic rock. Rocks comprising this sheet include gabbro, amphibolite, dunite, troctolite, magnetite-rich pyroxenite, serpentinite, and talc schist. The surface rocks comprise the Hayesville thrust sheet and correlate with the Richard Russell Formation of Gillon (1982) of probable Late Proterozoic age. Rocks of the Great Smoky thrust sheet underlie the Hayesville thrust sheet. Hayesville thrust sheet rocks in the study area include biotite gneiss, biotite schist, finegrained biotite-feldspar gneiss, metasandstone, graywacke, amphibolite, hornblende gneiss, granitic gneiss and some migmatite of biotite gneiss and granite. In addition, numerous discontinuous quartz and pegmatite veins and irregular pegmatite pods of varying size are widely dispersed throughout these rocks. The area approximately $330 \mathrm{ft}$ southeast of the study area is underlain by a lower-grade metamorphic sequence of interlayered metasandstone quartzite, metagraywacke, graphite-bearing garnet-mica schist, and thin to thick layers of amphibolite of the Helen belt (Nelson, 1982). The Helen belt is separated from the Hayesville sheet by a thrust fault. Late Proterozoic-age rocks of the Ocoee Supergroup (Higgins and Zietz, 1975), which are part of the Great Smoky thrust sheet, are exposed northwest of the mafic-ultramafic rocks. The Ocoee rocks consist primarily of interlayered mica schist and metasandstone.

The metasedimentary rocks are interlayered at all scales, but bedding is seldom preserved. Instead, a discontinuous compositional layering is commonly seen. This layering is probably the result of metamorphic differentation and transposition of the bedding into the regional foliation. With the exception of quartz veins and some pegmatites, all the rocks possess a strong regional foliation. The layering in most metasedimentary rocks ranges from 1 to $6 \mathrm{in}$. in thickness.

Rocks underlying the study area have been complexly folded, and some exposures show that the rocks have been deformed by several generations of folding. Hatcher (1976, p. 17; and oral commun., 1979) reports as many as six phases of folding in similar rocks exposed elsewhere in the Hayesville thrust sheet. The second-generation folds form the major northeast-trending regional folds. Later phase folds are open to tight, upright to slightly overturned, and are northwest trending.

Although numerous thrust faults characterize the southern Appalachian Mountains, faults with large displacements were not observed, except for the faults bounding the Hayesville sheet in and near the study area. However, numerous small faults with displacements ranging from several inches to a yard or more are common. Locally some ductile shear zones and narrow mylonite zones are also present.

Rocks of the Hayesville sheet within the study area are in the sillimanite zone of regional Barrovian metamorphism, as all compositionally favorable rocks contain sillimanite. The rocks are highly migmatitic and contain many irregular granitic masses. In addition, anatectic melt material and feldspathic segregations are widespread. Sillimanite is widely distributed, generally in rocks with a low muscovite content. These rocks were metamorphosed about 450$480 \mathrm{~m} . \mathrm{y}$. ago, probably during the Taconic orogeny (Butler, 1972; Dallmayer, 1975). The granitic rocks and pegmatites were probably intruded at about the time of peak metamorphism.

Some prograde metamorphic minerals were retrogressively altered. Sillimanite is locally altered to sericite, some plagioclase is saussuritized, and some garnet and biotite have altered rims of chlorite. The ultramafic-mafic rocks are commonly chloritized.

\section{GEOCHEMICAL SURVEY}

A reconnaissance geochemical survey was undertaken to determine if any unidentified mineral deposits exist within the Chattahoochee Roadless Area (Koeppen and Nelson, in press). Samples of bedrock, stream sediments, and alluvial panned concentrates were analyzed by the 31-element, emissionspectrographic method. Most of the samples contain normal elemental abundances and distribution. Non- 


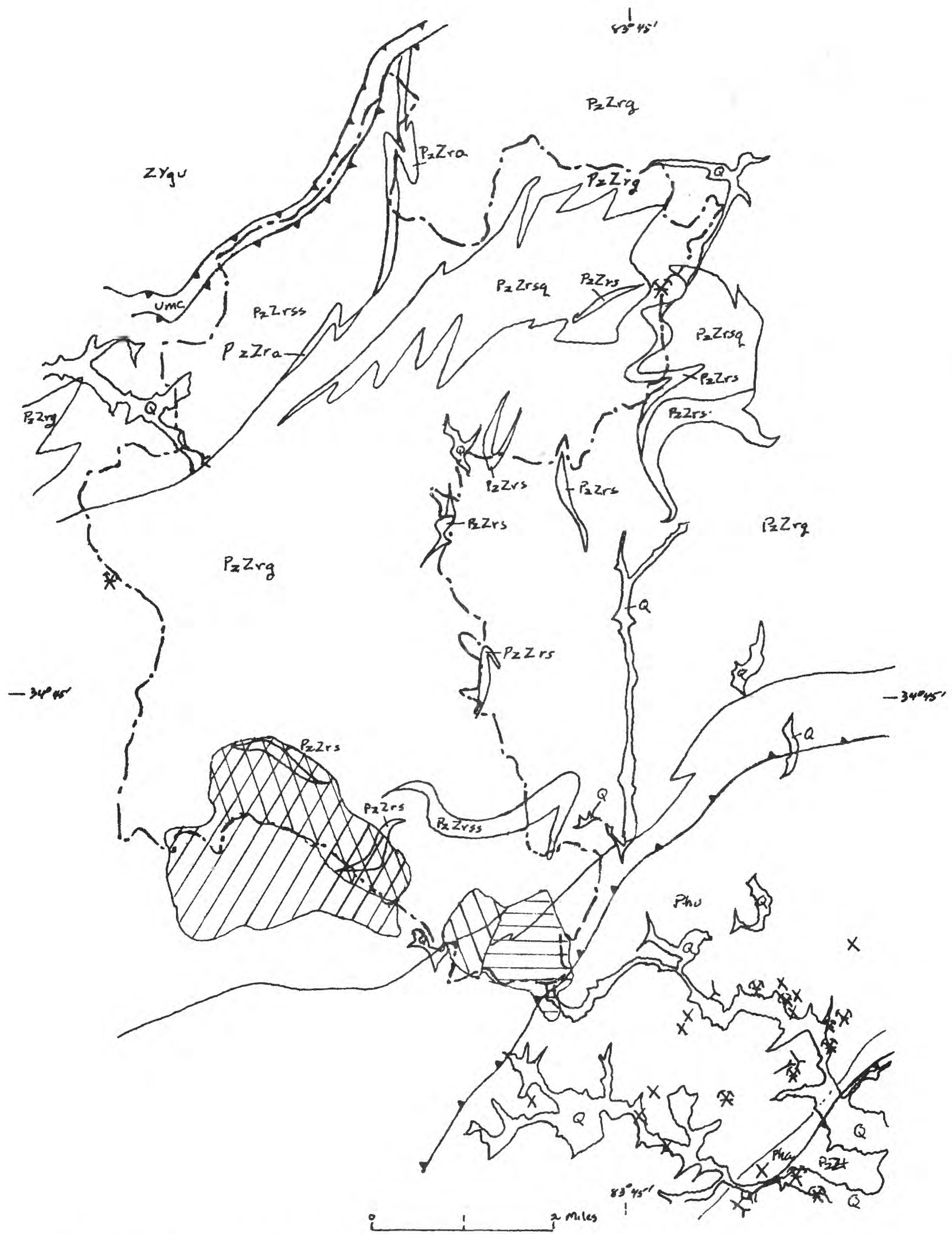

Figure 2.--Geologic map of the Chattahoochee Roadless Area showing areas having elemental concentrations. 
EXPLANATION OF MAP UNITS
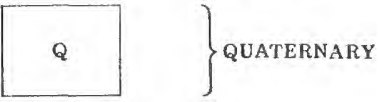

Unconformity

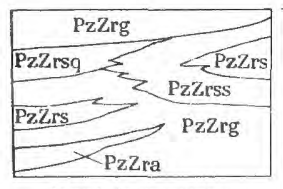

Break in sequence

LOWER

ALEOZOIC

PROTEROZOIC \&

pzZt

Break in sequence

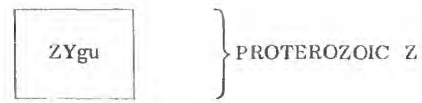

Break in sequence

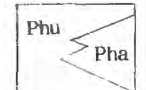

PROTEROZOIC

Break in sequence
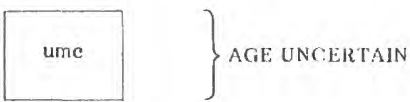

DESCRIPTION OF MAP UNITS

Quaterıary deposits-Unconsolidated colluvium and alluvium. Coarse bouldery and cobbly gravels, sand, and clay. Colluvial materials cover many slopes and are thickest along lower slopes of steep valley walls; colluvium merges into alluvial fan deposits; streams commonly choked with bouldery debris Alluvial deposits are fine-textured gravels and sand, present in all stream valleys; thickest and sand, present in all stream valleys; thi

Unnamed lower Paleozoic and(or) Proterozoic Z biotite gneiss, metasandstone; mica schist, amphibolite and hornblende gneiss, granite gneiss, an quartzite assemblage that is informally called the "Richard Russell group" (K. A. Gillon, written commun., 1979) $)_{i}$ exceptionally well exposed along the nearby Richard Russell Highway

Chiefly biotite gneiss variably interlayered with and gradational into metasandstone, alternates with thin to thick layers of biotite schist, muscovitebiotite schist, hornblende gneiss and amphibolite calc- silicate layers, minor gabbroic dioritic, and calc- silicate layers, minor gabbroic dioritic, and granite gneiss-Biotite gneiss, medium-gray to brownish-gray, medium-to coarse-grained, locally porphyroblastic, irregularly layered to massive, principally contains biotite, feldspar, and garnet, with lesser amounts of muscovite, epidote, sphene, and sulfides. Commonly light-felsic and dark-biotite segregations form major parts of exposures. Pegmatites and granite pods and veins common

Mostly metasandstone variably interlayered with and gradational into biotite gneiss, interlayered with biotite schist, muscovite-biotite schist, hornblende gneiss, and amphiboliteMetasandstone, feldspathic with quartz and eldspar dominant to argillaceous, light-green to brownish-gray, fine- to medium-grained, locally contains pebble layers, thinly to thickly layered, containing garnet, plagioclase, biotite, quartz, with minor epidote, sphene and sulfides. Locally metasandstone has numerous very thin quartzofeldspathic segregations alternating with very thin dark biotite streaks. Discontinus pegmatite and quartz veins and pods are common

Feldspathic quartz-rich metasandstone, light-gray, fine-grained, and thinly layered, is closely with light-tan to light-gray quartzite. Locally rich in epidote and some muscovite

Biotite schist and muscovite-biotite schist interlayered with metasandstone, biotite gneiss, and some granite gneiss-Biotite schist, gray to dark-brown, medium- to cosrse-grained, irregularly layered to massive, containing biotite, feldspar, quartz, sillimanite, and locally abundant garnet, in places muscovite nearly equal to biotite, sericite clusters present, locally has some chlorite and graphite; calc-silicate layers, felsic serregations, segregations, granite and pegmatite voins and
pods are all common
Amphibolite-Dark-greenish-gray to black, fine- to medium-grained amphibolite thinly laminated and locally with thin black mafic and light felsic tripes contains mostly plagioclese and actinolite stripes; contains mostly plagioclase and actinolit or hornblende, with some garnet, biotite, epidote, chlorite, and quartz. Locally grades into
hornblende gneiss and in places associated with metagabbro

PzZt

Alternating sequence of migmatitic impure metasandstone and graywacke, biotite gneiss, biotite schist, and amphibolite of the Tallulah Falls Formation, includes some granitic gneiss

ZYgu

Undivided Proterozoic $\mathrm{Z}$ rocks of Great Smoky thrust sheet exposed in window through Hayesville thrust sheet-Rocks believed to be part of Ocoee Supergroup, they consist of alternating beds of metasandstone and mice schist; includes some bodies of granite gneiss. Mice schist, thinly to bodies of granite gneiss. Mica schist, thinly to thichly layered, containing garnet, feldspar, biotite and a lesser anount of muscovite, locally some chlorite, and sulfides present, quartzofeldspathic segregations common, sillimanite fresent in more aluminous layers. Metasandstone, medium- to dark-gray, fine- to medium-grained, thinly to thickly bedded, contains feldspar, muscovite, biotite, and quartz, Iocally abundant garnet and epidote. Some granite and quartzofeldspathic lenses present especially in more schistose units; some calcsilicate layers, lenses and pods also present

Helen belt rocks - Chiefly undivided alternating Proterozoic metasandstone and mica schist beds with minor interlayered metagraywacke, metasiltstone, and quartzite, includes some amphibolite. Metasandstone generally feldspathic, light- to medium-gray, locally with some rare pebble beds, fine-to m, locally with some rare pebble beds, fine- to medium-grained, thin- to thickly layered, containing mostly feldspar, muscovite, and quartz with minor garnet and epidote. Schist, medium-gray, medium- to coarse-grained generally thinly leyered; contains garnet, plagioclase, and microcline. Quartz-mice schist, contains more muscovite than biotite, has minor chlorite and sulfides. Silver-gray, coarsegrained, graphite, garnet, staurolite, and plagioclase muscovite schist, contains minor biotite, chlorite, sphene, and tourmaline. Medium- to dark-gray, fine- to coarse-grained, generally thinly layered plagioclase, quartz-mica schist, conteins more muscovite than biotite, minor currta sulfides, and chlorite. Derkt minor quartz, sulfides, and chlorite. Dark-gray metagraywacke; medium-gray, fine-grained metasiltstone, and light-gray epidote quartzite are interlayered with dominant metasandstone and schist units

Pha

Amphibolite-Dark-gray to black, finely laminated, fine- to medium-grained, thinly layered to massive, amphibolite containing chiefly plagioclase, actinolite, and amphibole, with minor quartz, epidote, biotite, and chlorite. Interlayered with minor medium-gray, finegrained, thinly. layered metasiltstone and guartzite beds

Uttramafic-mafic complex-Dark-greenish-brown, medium- to coarse-grained two-pyroxene rock rich in magnetite and dark-greenish-gray, medium- to coarse-grained deeply weathered rock medium- to coarse-grained deeply weathered rock some amphibolite that is black and fine grained is some amphibolite that is black and fine grained is included with these rocks, includes some darkgreenish-gray, fine- to medium-grained talc-
chlorite schist, and some altered greenish-gray, medium-grained dunite

EXPLANATION

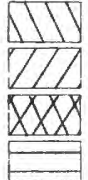
$\mathrm{Zn}=1000 \mathrm{ppm}$ $\mathrm{Sn}=200-300 \mathrm{ppm}$

$\mathrm{Sn}=300 \mathrm{ppm}$

$\mathrm{Zn}=1000 \mathrm{ppm}$

$\mathrm{Be}=100-200 \mathrm{ppm}$

Contact-Approximately located; dashed where coneealed

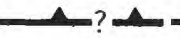

Thust fault-Approximately located; sawteeth on upper plate. Dashed where concealed; queried where probable Prospect

$\longrightarrow$ Mine

-+ Mine, abandoned 


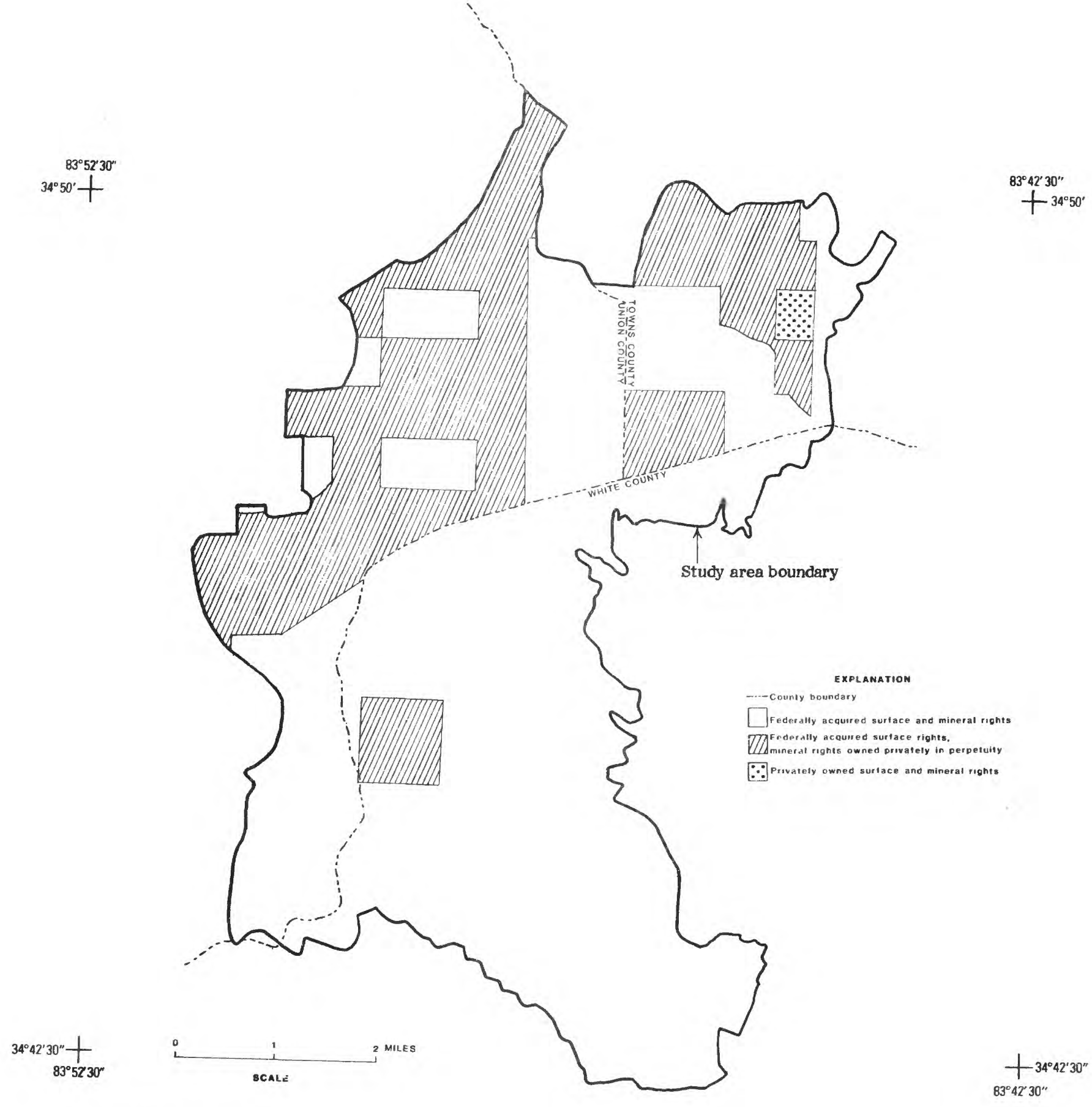

Figure 3.-Surface- and mineral-rights ownership, Chattahoochee Roadless Area, Ga. 

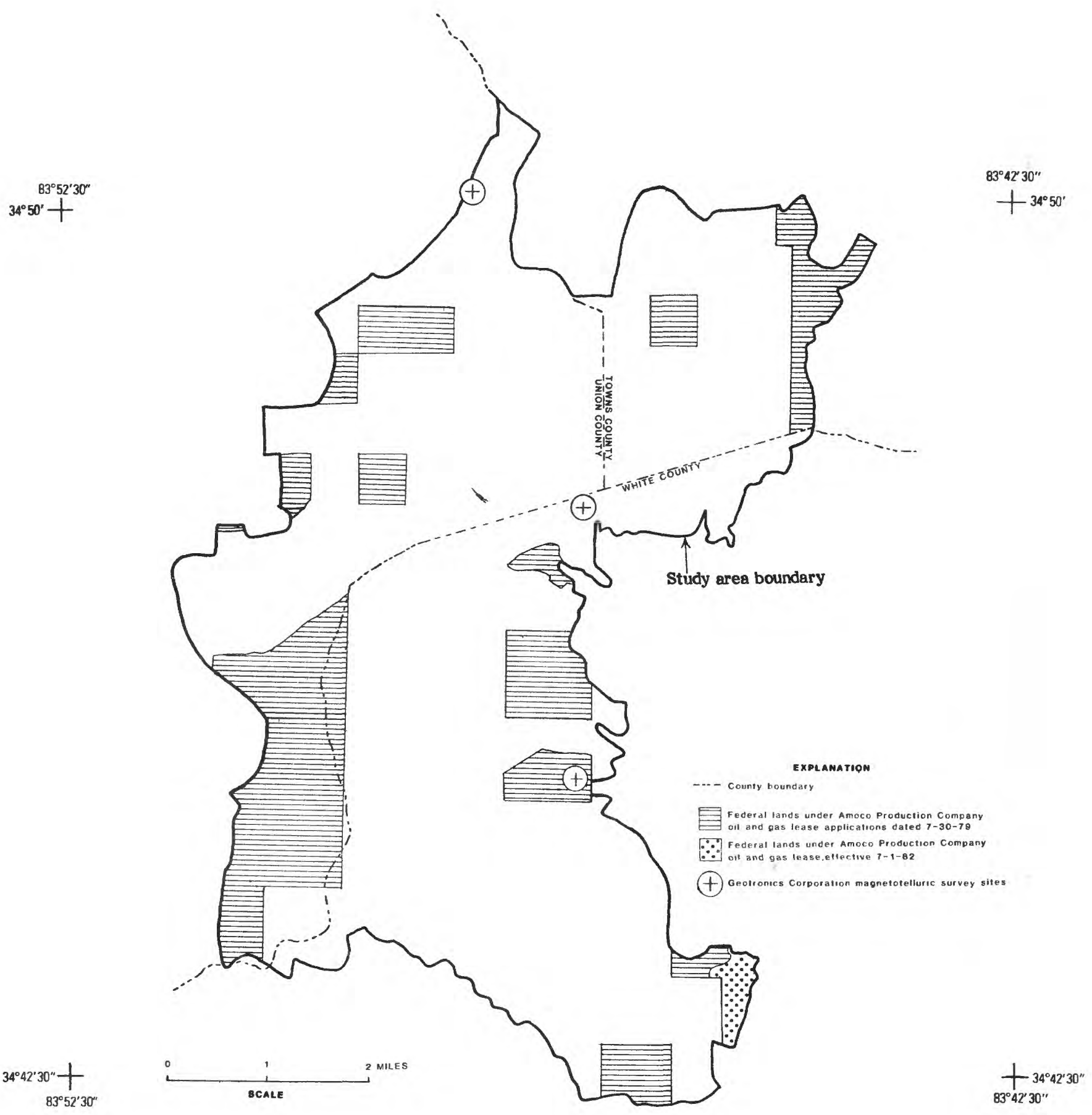

(†)

Figure 4.--Oil and gas leasing and exploration, Chattahoochee Roadless Area, Ga. 
magnetic fractions of several panned concentrates from streams along the southern border of the area have moderately enriched abundances of zinc (1000 $\mathrm{ppm}$ ) and tin (200-300 ppm), but no other evidence was found for concentrations of these metals in the study area. The tin is probably in the form of cassiterite, since it is only in the non-magnetic fraction. The nature of the occurrence is not known, but it seems likely that these anomalous abundances of tin and zinc represent only small localized concentrations and are not indicative of a hidden mineral deposit. Nonmagnetic fractions from two other stream concentrates taken along the south edge of the area have beryllium abundances of 100-200 ppm. The source of the anomalous beryllium is not known; however, it may be related to minor concentrations of accessory minerals derived from Helen belt rocks which partially underlie these drainage basins, or possibly to mineralization associated with fluid migration along the Shope Branch fault during one or more thermal events.

\section{MINERAL RESOURCE POTENTIAL}

Rocks for use as construction material and for landscaping form a potential resource, but no metallic resources are known in the Chattahoochee Roadless Area, and no evidence of a potential for concealed mineral deposits was found in the geochemical survey (Koeppen and other, in press) or in the geophysical survey (Daniels, 1983). Although gold, mica, asbestos, and olivine have been mined in nearby areas, there is a low potential for these commodities in the study area. The potential for oil or gas from deeply buried rocks under the Hayesville and other regional thrust sheets is untested.

\section{Construction Materials}

Much of the rock underlying the study area is suitable for use as crushed rock, aggregate, or landscaping. One small quarry in biotite gneiss is located at the northeast corner of the study area. Because there are good sources for aggregate and crushed stone closer to major markets, there is no immediate use for rock in the study area as a source for construction materials.

\section{Gold}

There is no recorded gold mining in the Chatahoochee Roadless Area, but in the Nacoochee district, $1 \mathrm{mi}$ to the southeast, gold has been intermittently mined for the last 150 years (Koschmann and Bergendahl, 1968). The most recent mining in this district was a small gold placer in Dukes Creek that was operated by Dale Jackson of Helen, Ga. from 1978 to 1981 . The fact that all known local gold mining has been confined to rocks of the Helen belt suggests that the gold deposits are geologically controlled by factors unique to the Helen belt, although a few small deposits are known in rocks of the Hayesville thrust sheet not more than ten miles to the northeast (Nelson and others, 1983). Hurst and Otwell (1964) found minor amounts of gold particles in concentrated alluvial samples from Jasus and Low Gap Creeks, near the eastern boundary of the study area. However, these authors remark that the use of goldbearing gravels as road metal in the local area makes interpretation of gold anomalies uncertain. Analyses of sluiced and panned concentrates collected from the same streams during the present field reconnaissance revealed no gold (Koeppen and Nelson, in press; Welsh and Mikolajczyk, 1982). The only gold found during this study was one particle in a panned concentrate of sediments from the Left Fork of the Notteley River (Welsh and Mikolajczyk, 1982, p. 15). This gold occurrence is not considered to be indicative of a potential resouce.

\section{Other Mineral Commodities}

Minerals associated with the mafic-ultramafic rocks in the region include asbestos, soapstone, corundum, olivine, the metallic accessory mineral chromite, and minerals that contain nickel and platinum. Examination and sampling of maficultramafic bedrock at the northwestern corner of the study area indicate the presence of impure soapstone and dunite, both of negligible value. Chromite and nickel contents of sampled bedrock are well below minable concentrations and platinum was not detected. No asbestos or corundum was found.

Pegmatites that crop out in the study area are small, unzoned pods consisting of biotite and muscovite mica, quart $z$, and feldspar. The muscovite mica is of poor quality and has negligible value. The sillimanite and kyanite content of sampled metamorphic rocks of the Hayesville thrust sheet is too low to constitute a refractory or aluminum source.

An occurrence of autunite, a uranium phosphate mineral, has been reported about $1 \mathrm{mi}$ south of the study area (Hurst and Otwell, 1964). Gamma ray scintillometer and spectrometer examinations of pegmatites in the study area revealed no radioactive source significantly above background levels.

Small quantities of alluvial scheelite were reported from the Chattahoochee River just east of the study area (Hurst and Otwell, 1964) and from the Dukes Creek floodplain (Lynch, 1953). Ultraviolet irradiation of alluvial concentrate samples from streams draining the study area revealed no scheelite.

Several panned concentrates of stream gravels are slightly enriched in tin, but there is no other evidence indicating that significant concentrations of tin are present in the study area.

\section{Rare-earth elements}

Lanthanum and yttrium were detected in all panned and sluiced alluvial sediment samples collected from streams draining the area, and a special spectrographic analysis detected cerium, ervium, dysprosium, and neodymium in an alluvial sample collected south of the study area from a stream draining part of the study area (Welsh and Mikolajczyk, 1982 , p. 14). The highest lanthanum value of 4,000 $\mathrm{ppm}$ and the highest yttrium value of $2,000 \mathrm{ppm}$ were from a sluced sample. The rare earth elements that were detected are attributed to monazite and xenotime grains present in the concentrated sediment samples. These detrital heavy minerals have been weathered from low-tenor accessory-mineral occurrences in bedrock upstream from the sample sites. Monazite and xenotime were collected by Mertie (1979) from streams draining biotite gneiss and schist bedrock areas in northern Georgia; occurrences of monazite in the Chattahoochee Roadless Area 
suggest a northwestward extension of his "mountain monazite belt." Further sampling and analysis would be required to determine the bedrock source of the accessory minerals that contain rare earth elements.

\section{Hydrocarbons}

Recent data from COCORP seismic-reflection surveys suggest that lower Paleozoic sedimentary strata under ie the Blue Ridge Precambrian rocks (Cook and others, 1979). Projections of seismic data into the study area show that a thickness of nearly 5 mi of crystalline rocks overlies this sedimentary sequence. Sedimentary rocks that contain hydrocarbons in the Tennessee Valley may form a part of the sedimentary sequence underlying the regional thrust sheets in the Chattahoochee Roadless Area. Hatcher (1982) discussed the hydrocarbon potential of these buried sediment and concluded that hydrocarbon stability is unlikely beneath much of the Blue Ridge because of the probable high temperatures present at depth. If hydrocarbons are present, they would probably be in the form of gas, and deep drilling is necessary to prove the presence of gas before reliable estimates of the gas potential can be made.

\section{REFERENCES CITED}

Butler, J. R., 1972, Age of Paleozoic regional metamorphism in the Carolinas, Georgia, and Tennessee southern Appalachians: American Journal of Science, v. 272, p. 317-333.

Cook, F. A., Albaugh, D. S., Brown, L. D., Kaufman, Sidney, Oliver, J. E., and Hatcher, R. D., Jr., 1979, Thin-skinned tectonics in the crystalline southern Appalachians; COCORP seismicreflection profiling in the Blue Ridge and Piedmont: Geology, v. 7, no. 12, p. 563-567.

Crickmay, G. W., 1952, Geology of the crystalline rocks of Georgia: Georgia Geological Survey Bulletin 58, 54 p.

Dallmayer, R. D., 1975 , Incremental ${ }^{40} \mathrm{Ar} /{ }^{39} \mathrm{Ar}$ ages of biotite and hornblende from retrograded basement gneisses of the southern Blue Ridge; their bearing on the age of Paleozoic metamorphism: American Journal of Science, $v$. 275 , no. 4, p. 444-460.

Daniels, D. L., in press, Aeromagnetic map and analysis of aeromagnetic and aeroradioactivity data in the Blood Mountain, Chattahoochee, and Tray Mountain Roadless Areas, Northern Georgia: U.S. Geological Survey Miscellaneous Field Studies Map MF-1347-B.

Furcron, A. S., and Teague, K. H., 1943, Mica-bearing pegmatites of Georgia: Georgia Geological Survey Bulletin 48, 192 p.

Geological Survey of Georgia, 1976, Geologic map of Georgia: Georgia Geological Survey Map GM-7, scale 1:500,000.

Gillon, K. A., 1982, Stratigraphic, structural and metamorphic geology of portions of the Cowrock and Helen Georgia 7.5' quadrangles: unpublished M.S. thesis, University of Georgia, Athens, Georgia, 236 p.

Hartley, M. E., III, 1973, Ultramafic and related rocks in the vicinity of Lake Chatuge: Georgia Geological Survey Bulletin 85, 61 p.

Hatcher, R. D., Jr., 1971, The geology of Rabun and Habersham Counties, Georgia: Georgia Geological Survey Bulletin 83, 48 p.
1974, Introduction to the tectonic history of northeastern Georgia: Geological Survey Guidebook 13-A, p. 59-60.

1976 , Introduction to the geology of the Eastern Blue Ridge of the Carolinas and nearby Georgia: Carolina Geological Society guidebook, 53 p. 1982, Hydrocarbon resources of the Eastern Overthrust Belt: Science, v. 216, p. 980-982.

Higgins, M. W., and Zietz, Isidore, 1975, Geologic interpretation of aeromagnetic and aeroradioactivity maps of northern Georgia: U.S. Geological Survey Miscellaneous Geological Investigations Map I-783.

Hurst, V. J., 1973, Geology of the southern Blue Ridge belt: American Journal of Science, v. 273, no. 8, p. 643-670.

Hurst, V. J., and Otwell, W. L., 1964, Exploration for mineral deposits in White County: Washington, D.C., U.S. Department of Commerce, ARA Contract no. Ce-5960, 166 p.

Koeppen, R. P., and Nelson, A. E., in press, Geochemical survey of the Chattahoochee Roadless Area, Towns, Union, and White Counties, Georgia: U.S. Geological Survey Miscellaneous Field Studies Map MF-1502-B.

Koschmann, A. H., and Bergendahl, M. H., 1968, Principal gold-producing districts of the United States: U.S. Geological Survey Professional Paper 610, 283 p.

Lynch, V. J., 1953, Letter listing tungsten localities in Georgia: unpublished data on file in Pittsburgh, Pa. at Eastern Field Operations Center, U.S. Bureau of Mines, $2 \mathrm{p}$.

Mertie, J. B., Jr., 1979, Monazite in the granite rocks of the Southeastern Atlantic States - an example of the use of heavy minerals in geologic exploration: U.S. Geological Survey Professional Paper 1094. $79 \mathrm{p}$.

Nelson, A. E., 1982, Geologic map of the Tray Mountain Roadless Area, northern Georgia: U.S. Geological Survey Miscellaneous Field Studies Map MF-1347-A, scale 1:30,000.

1983, Geologic map of the Chattahoochee Roadless Area, Towns, Union, and White Counties, Georgia: U.S. Geological Survey Miscellaneous Field Studies Map MF-1502-A, scale $1: 30,000$.

Nelson, A. E., Koeppen, R. P., and Chatman, M. L., 1983, Mineral resource potential map of the Tray Mountain Roadless Area, Northern Georgia: U.S. Geological Survey Miscellaneous Field Studies Map MF-1345-C.

Siems, D. F., Forn, C. L., Koeppen, R. P., and Nelson, A. E., in press, Geochemical data and descriptions of samples from Tray Mountain, Blood Mountain, and Chattahoochee Roadless Areas, northeast Georgia: U.S. Geological Survey Open-File Report, 50 p.

Welsh, R. A., Jr., and Mikolajczyk, R. W., 1982, Mineral investigation of Chattahoochee River RARE II Further planning Area, Towns, Union, and White Counties, Georgia: U.S. Bureau of Mines Open-File Report MLA 140-82, 25 p.

Yeates, W. C., McCallie, S. W., and King, F. P., 1896, A preliminary report on a part of the gold deposits in Georgia: Georgia Geological Survey Bulletin 4-A, 542 p. 


$$
\text { : }
$$

